\title{
Welfare in pig housing - Brazilian and Portuguese legislation
}

\author{
Daiane Cecchin - Francine Aparecida Sousa - Pedro Ivo Sodré Amaral • \\ Jaqueline de Oliveira Castro - Dirlane de Fátima do Carmo - Patrícia Ferreira Ponciano Ferraz • \\ Alessandro Torres Campos • Vasco Manuel Fitas da Cruz
}

D Cecchin (Corresponding author) - DF Carmo

Department of Agricultural Engineering and Environment Universidade Federal Fluminense (UFF), Niterói, RJ, Brazil. email: daianececchin@id.uff.br

\section{FA Sousa}

SEMAG/Aracruz, ES, Brazil.

\section{JO Castro - PFP Ferraz - AT Campos}

Universidade Federal de Lavras (UFLA), Lavras, MG, Brazil.

PIS Amaral

Universidade José do Rosário Vellano (UNIFENAS), Alfenas, MG, Brazil.

\section{VMF Cruz}

Universidade de Évora (UE), Portugal.

Received: January 24, 2018 - Revised: April 05, 2018 • Accepted: April 05, 2018

\begin{abstract}
Animal welfare is conditional on well-planned and well-managed exploitation, since the management of the animals strongly influences their behavior, their productivity and, consequently, the yield and quality of the final product. In this study, an investigative review was carried out of the literature, governmental databases and main institutions relating to animal welfare, seeking to highlight and discuss differences in legislation between Brazil and Portugal, in view of the interest and concern of the scientific community and the consumer market in relation to methods used for animal production. In Brazil, there is no specific legislation on the welfare of pigs and other related legislation is used as a basis. However, Portugal has more specific legislation on the subject. Considering the dissemination of knowledge and the growing concern with animal welfare in the European consumer market, it is noted that the need for its application standards that ensure animal welfare in production/breeding, possibly becoming a basic requirement in the coming years. However, Brazilian pig farms, like all other animal production activities, are still lacking specific legislation that is appropriate for Brazil, which ends up delaying the effective practice of welfare in productions, abstaining from the population of information about the activity. New studies are needed to ascertain the necessity and applicability of the legislation, and whether the legislation is effective in improving animal welfare or serves only to increase bureaucracy.
\end{abstract}

Keywords: laws, pigs, rural buildings

\section{Introduction}

There is a growing concern among the general public, the scientific community and the consumer market with regard to the methods used in breeding animals for meat production. The new requirements of the external market, in relation to the ethical quality of the products available for consumption, require new techniques directed at animal welfare (Foppa et al 2014). As a result, the concept of animal welfare is gaining more and more importance, which has led to major changes in European legislation regarding standards for rearing pigs and other animals (Cruz and Grácio 2005).

According to Galina and Pfüller (2015), the quality of the meat should be understood as a legal and ethical obligation of all the links involved in the production chains and not only with a demand of the consumer market.

Animal welfare is undoubtedly conditional on wellplanned and managed production. The management of animals and the way they are treated strongly affects their productivity, behavior and, consequently, the final yield of livestock farms, since it is a factor that enhances the quality and quantity of the final product (CAP 2006). In animals, stress represents a potential threat to homeostasis and the central nervous system is stimulated to act. This action is reflected in four types of responses: behavioral, those associated with the autonomic nervous system, and the neuroendocrine and immune systems (Cruz et al 2004). Stress can result in different responses in the meat, such as a dark, firm and dry (DFD) or pale, soft and exudative (PSE) appearance (Barbut et al 2008; Ordóñez 2005).

Increasingly, consumers are concerned about the origin and the mode of production of the goods they consume, demanding that the meat on their plate has been produced, transported and slaughtered in accordance with animal welfare standards (CAP 2006). Currently definitions of animal welfare involve recognition of the following five freedoms specified by the Farm Animal Welfare Council (FAWC) in the United Kingdom: 1 - physiological freedom; 2 - environmental 
freedom; 3 - freedom of health; 4 - behavioral freedom; 5 psychological freedom (FAWC 2009).

According to Broom (1991), suffering is usually related to welfare, but commitment to welfare is not necessarily synonymous with suffering. According to Machado Filho and Hötzel (2000), poor animal welfare should not be confused with animal cruelty, since cruelty to the animal is the deliberate, sadistic, and unnecessary infliction of pain, suffering and neglect on animals. Social ethics condemn cruelty to and mistreatment of animals.

In general, the recommendations and codes of good practice take into account the theoretical framework provided by the five freedoms when defining areas of action to improve animal welfare on farms, since compliance with the latter is essential to safeguard this aspect in any production system (CAP 2006).

The intensification of pig production in traditional confinement systems generates controversy over animal welfare or lack thereof. While there is rigid legislation in Portugal, following the recommendations of the European Union in Brazil, this topic has little effective application, since there is no imposition of the Brazilian consumer. For the time being, the only situation of animal welfare injunction in Brazilian pig farms would be the requirements of the external market (Maia et al 2013).

The objective of this study was to carry out an investigative review of the literature, seeking to highlight and discuss differences between Brazil and Portugal in terms of the legislation relating to animal welfare.

\section{Concern about animal welfare}

At the end of the twentieth century and the beginning of the 21st century, there was an increase in the level of demands concerning the quality of food products by consumers around the world, particularly with respect to hygiene and the quality of life of workers and animals involved in production. People began to want meat from animals that were raised, treated and slaughtered in systems that promoted welfare, defined as "ethical quality", and that the production system was sustainable under environmentallyfriendly conditions (Warriss et al 2006).

In Brazil, research developed taking into account the perception of consumers has been carried out. For example, the study by Franchi et al (2012a) in Piracicaba (state of São Paulo) it was found that more than $90 \%$ of consumers stated that they were aware that production animals expressed feelings, although high perception on the subject, only $36.9 \%$ of consumers take this into account when purchasing the product. However, there has been a steady increase in this value, due to access to information about the way animals are raised. In a study by Queiroz et al (2014) in Fortaleza (state of
Ceará), it was observed that consumers were willing to pay more for certified products that guaranteed animal welfare.

With increasing consumer concern the European Union (EU) has realized the evident need to discuss animal welfare in the context of the World Trade Organization (WTO). The subject is of interest to both consumers and producers. In view of the interrelationship between animal welfare measures and international trade in agricultural products and foodstuffs of animal origin, the EU considers that this issue should be addressed in the context of the agriculture and livestock negotiations, with a view to establishing a standards that characterize welfare requirements in animal production, effectively characterizing the technical barriers to commercialization (Pandorfi 2005).

The first general law on animal welfare appeared in the year 1822 in Great Britain. However, the first principles of animal welfare began to be studied in 1965 by a committee of researchers and practitioners related to agriculture and animal husbandry in the United Kingdom, called the Brambell Committee, who initiated a more in-depth study of definitions of animal welfare. This committee was a response to pressure from a population outraged by the ill-treatment of animals in containment systems reported in the book, Animal Machines, by the English journalist Ruth Harrison in 1964 (Ludtke et al 2010).

The concern for animal welfare in Brazil is not recent. In 1934, President Getúlio Vargas approved the first Law on the Protection of Animals, Decree $\mathrm{N}^{\circ}$. 24.645. This condemned the mistreatment of animals used in public or private places, and a person could pay a fine or be arrested, whether or not they owned the animal. In 1952, the Regulation of Industrial and Sanitary Inspection of Products of Animal Origin (RIISPOA) was published, in accordance with Decree No. 30.691/1952. This provided some specific standards for each species. However, it is Normative Instruction 03/2000, with the technical regulation of stunning methods for humane slaughter that has placed more emphasis on this issue (Ministério da Agricultura e do Abastecimento 2000). In 2008, the Normative IN 56/2008 was issued, with recommendations of good welfare practices for production animals and Economic Interest (MAPA 2008). Two years later was publish the Circular 12 (March 2010), the circular brings changes and adaptations of Circular 176/2005. This assigned responsibility to federal inspectors for the on-site and documentary verification of animal welfare through standardized official spreadsheets (MAPA 2010).

According to Franchi et al (2012b), currently in Brazil there are a number of state animal protection laws and draft laws, such as PL 215/2007, which establishes the Federal Animal Welfare Code, state code for animal protection for Rio de Janeiro (Law No. 3900/2002), Paraná (Law No. 14.037/2003), Rio Grande do Sul (Law No. 11.915/2003), 
Santa Catarina (Law No. 12.854/2003), São Paulo (Law Nº. 11.977/2005), Espírito Santo (Law Nº. 8.060/2005).

The introduction of standards that aim to achieve greater comfort and animal welfare in pig units in Portugal occurred through the publication of Ordinance $N^{\circ}$. 274/94 of May 7, it is specifies actions to be taken, such as the control of temperature, humidity, gases and luminosity, the need for an area for movement of animals in relation to their age, abolition of collars as a form of containment in gestation cells, facilities which allow visual contact between the animals, and periodic monitoring of the functioning and condition of the equipment (Ministério da Agricultura 1994).

In 2000, Decree-Law $N^{\circ} 64 / 2000$ of 22 April, transposing into national law Council Directive 98/58 /EC of 20 July, requires the owner or keeper of the animals to implement all measures that are necessary for the welfare of the animals in their care, ensuring that they are not exposed to unnecessary pain, injury or suffering. The Decree-Law 135/2003 of 23 June and Annex "A" of Decree-Law N ${ }^{\circ}$
64/2000 of 22 April specify that animals must be cared for by a qualified and competent person, since the producer has a major influence on animal welfare (MADRP 2000; MADRP 2003).

\section{Housing}

In the construction or modification of agricultural and livestock facilities there should be technical monitoring to ensure the welfare of the animals that will be housed there. The Decree-Law No. 135/2003 of 28 June specified in its annex that housing for pigs should allow animals to move without difficulty, to be a clean, dry and comfortable place to rest, have a floor which is smooth and not slippery, and have concrete gratings with defined widths and openings (Table 1). A poorly constructed pavement, grids not adjusted to the physical conditions of the animals and poorly maintained surfaces can cause injuries to the legs of animals (MADRP 2003).

Table 1 Dimensions of pig housing specified in Portuguese legislation according to age/weight of the pig.

\begin{tabular}{|c|c|c|c|}
\hline Average weight & $\begin{array}{l}\text { Area per animal } \\
\text { (minimum space) }\end{array}$ & $\begin{array}{l}\text { Concrete grid (Maximum } \\
\text { opening) }\end{array}$ & $\begin{array}{l}\text { Concrete grid (Maximum } \\
\text { width) }\end{array}$ \\
\hline less than $10 \mathrm{~kg}$ & $0.15 \mathrm{~m}^{2} \mathrm{pig}^{-1}$ & $11 \mathrm{~mm}$ for piglets & $50 \mathrm{~mm}$ for piglets \\
\hline between 10 and $20 \mathrm{~kg}$ & $0.20 \mathrm{~m}^{2} \mathrm{pig}^{-1}$ & $11 \mathrm{~mm}$ for piglets & $50 \mathrm{~mm}$ for piglets \\
\hline between 20 and $30 \mathrm{~kg}$ & $0.30 \mathrm{~m}^{2}$ pig $^{-1}$ & $14 \mathrm{~mm}$ for weaned piglets & $50 \mathrm{~mm}$ for weaned piglets \\
\hline between 30 and $50 \mathrm{~kg}$ & $0.40 \mathrm{~m}^{2} \mathrm{pig}^{-1}$ & $\begin{array}{l}18 \mathrm{~mm} \text { for growing/finishing } \\
\text { pigs, } 20 \mathrm{~mm} \text { for gilts and } \\
\text { breeding herd }\end{array}$ & $80 \mathrm{~mm} \mathrm{~mm}$ for growing \\
\hline between 50 and $85 \mathrm{~kg}$ & $0.55 \mathrm{~m}^{2} \mathrm{pig}^{-1}$ & $\begin{array}{c}18 \mathrm{~mm} \text { for growing/finishing } \\
\text { pigs, } 20 \mathrm{~mm} \text { for gilts and } \\
\text { breeding herd }\end{array}$ & $\begin{array}{l}80 \mathrm{~mm} \text { for growing/finishing } \\
\text { pigs, gilts and breeding herd }\end{array}$ \\
\hline between 85 and $110 \mathrm{~kg}$ & $0.65 \mathrm{~m}^{2} \mathrm{pig}^{-1}$ & $\begin{array}{l}18 \mathrm{~mm} \text { for growing/finishing } \\
\text { pigs, } 20 \mathrm{~mm} \text { for gilts and } \\
\text { breeding herd }\end{array}$ & $\begin{array}{l}80 \mathrm{~mm} \text { for growing/finishing } \\
\text { pigs, gilts and breeding herd }\end{array}$ \\
\hline greater than $110 \mathrm{~kg}$ & $1.00 \mathrm{~m}^{2}$ pig $^{-1}$ & $\begin{array}{l}18 \mathrm{~mm} \text { for growing/finishing } \\
\text { pigs, } 20 \mathrm{~mm} \text { for gilts and } \\
\text { breeding herd }\end{array}$ & $\begin{array}{l}80 \mathrm{~mm} \text { for growing/finishing } \\
\text { pigs, gilts and breeding herd }\end{array}$ \\
\hline
\end{tabular}

The pigs should be placed in groups with as little miscegenation as possible, and the total floor area of the housing should be sufficient to sleep, eat and exercise (Table 1) (MADRP 2003). Environmental enrichment is an alternative practice that aims to increase the quality of life of confined animals, stimulating the typical behaviors of the species, reducing stress and aimed at their psychic and physiological welfare (Veloni et al 2013).

In Portugal, the legislation that provides for environmental enrichment is Decree-Law N ${ }^{\circ} .135 / 2003$ of 28 June. This specifies that all pigs must have permanent access to a sufficient quantity of material, such as straw, paper chips, sawdust or a mixture of these, which does not have a deleterious effect on the health of the animals (MADRP 2003). The use of straw as environmental enrichment is common in Europe, but in Brazil's climate conditions, its use may be limited (Foppa et al 2014). Brazil still does not have specific legislation that covers the issue of environmental enrichment. Environmental enrichment allows pigs to settle, investigate, chew and play. Objects such as tires, balls and chains can meet some of the environmental and behavioral needs of pigs (CAP 2006; Guy et al 2013).

The Decree-Law No. $135 / 2003$ defines that air circulation, dust levels, temperature, relative air humidity and 
harmful gas concentrations should be kept within limits which are not harmful to animals. Pigs should not be kept in an environment that involves high temperatures and high levels of humidity (MADRP 2003). Abrupt fluctuations in temperature within the dwellings should be avoided for 24hour periods, since high temperatures generate stress and may lead to caudophagia or cause diseases such as pneumonia. When an artificial ventilation system is used, an alternative system should be available to ensure sufficient air renewal if the installed system fails; an alarm system must be available to warn of any system failure, which is fully inspected and tested at least once every seven days (MADRP 2003; CAP 2006).

There is no law specifically regulating animal welfare practices in Brazil, only Normative Instruction $\mathrm{N}^{\circ}$. 56, which provides some principles for protecting animal welfare from birth and throughout life, and covers issues such as feeding, handling and transportation (Presidência da República 2008). Some differences can be observed in relation to the facilities between Portugal and Brazil in Table 2.

Table 2 Differences in relation to facilities between Portugal and Brazil

\begin{tabular}{|c|c|c|}
\hline Parameter & Portugal & Brazil \\
\hline Nursing cage & Allowed until better solution obtained & Widely used \\
\hline $\begin{array}{l}\text { Mating cage ( } 4 \text { weeks after } \\
\text { copulation) }\end{array}$ & Allowed until better solution obtained & Widely used \\
\hline $\begin{array}{l}\text { Gestation cage ( } 4 \text { weeks after } \\
\text { copulation up to } 1 \text { week before birth) }\end{array}$ & $\begin{array}{l}\text { Existing pig farms: banned since } 2013 \text {. New pig } \\
\text { farms: banned since } 2003\end{array}$ & Widely used \\
\hline Collar for copulation or gestation & $\begin{array}{l}\text { Existing pig farms: banned since } 2006 . \text { New pig } \\
\text { farms: banned since } 2001\end{array}$ & Little used \\
\hline Bedding and distraction material & $\begin{array}{l}\text { Existing pig farms: required since } 2013 \text {; New } \\
\text { pig farms: required since } 2003 \text {. }\end{array}$ & Little used \\
\hline Area per animal (minimum space) & See Table 1 & Not applicable \\
\hline Dimensions of concrete grates & See Table 1 & Not applicable \\
\hline Noise levels & Maximum 85 dBA (constant) & Not applicable \\
\hline Lighting levels - artificial & $\begin{array}{c}\text { Minimum of } 40 \text { lux for a minimum period of } 8 \\
\text { hours per day }\end{array}$ & Not applicable \\
\hline
\end{tabular}

\section{Feeding and handling procedures}

The Decree-Law N ${ }^{\circ}$. 135/2003 states that all pigs must be fed at least once a day with a complete and appropriate diet for each age, provided in adequate quantity. All pigs older than two weeks of age must have permanent access to fresh drinking water (MADRP 2003; CAP 2006). Some differences between management practices in the two countries are listed in Table 3.

\section{Sanitary control}

The most basic requirement affecting animal welfare is linked to the maintenance of good sanitary conditions, which include hygiene, good production conditions and effective ventilation.

The Decree-Law No. 135/2003, establishes that, when necessary, sick or injured pigs should be temporarily isolated in wards with dry and comfortable beds (MADRP 2003). Annex A of Decree-Law N ${ }^{\circ}$. 64/2000 specifies that the owner or keeper of the animals must keep a record of the treatments given and the number of mortality cases verified at each inspection of the medicines used, including the place of purchase; these records must be kept for at least three years (MADRP 2000).

In an emergency, when the animal does not react to treatment or is in a painful and incurable condition, it must be slaughtered according the guidelines on humane slaughter (MADRP 1996).

\section{Transport}

Transport exposes pigs to potentially stressful conditions, such as embarkation and disembarkation difficulties, noise, vibration, abrupt changes in speed and variations in ambient temperature (Ludtke et al 2012).

The Decree-Law No. 294/98, of 18 September of Portugal and Normative Instruction $\mathrm{N}^{\circ} .03$ of 17 January 2000 of Brazil require that animals, when being loaded or unloaded, must not be suspended by any mechanical means, nor lifted or dragged by the head, feet or tail (MAPA 2000; MADRP 1998). Failure to carry out shipment-related maneuvers causes animal stress and increases the risk of accidents, which may 
result in reduced carcass yield and increased occurrence of hematomas (MAPA 2013).

Community Regulation Regulation No. 1/2005 of 22 December 2004 relating to the protection of animals during transport and related operations states that excessive force should never be used to control animals and that use of electric shocks, sticks or any other pointed instrument to control or beat the animals should be avoided (Conselho Europeu 2004). The embarkation of debilitated, malnourished, ill or injured animals should be avoided (MAPA 2013). According to Community Regulation No. 1/2005 of 22 December 2004, the minimum requirements for space during transport are that all pigs must at least be able to lie down and stand. The loading density of pigs of about $100 \mathrm{~kg}$ should not exceed $235 \mathrm{~kg} / \mathrm{m}^{2}$. This value can be increased depending on the breed, size and physical condition of the pigs, weather conditions and duration of the trip.

Table 3 Differences between management practices used in Portugal and Brazil

\begin{tabular}{|c|c|c|}
\hline Parameter & Portugal & Brazil \\
\hline Minimum weaning Age & 28 days & 21 days \\
\hline Castration & Allowed, if there is no tissue tear & Practiced \\
\hline Cutting teeth & $\begin{array}{l}\text { Allowed, but not routinely and only up to seven days of age; } \\
\text { avoided if possible. }\end{array}$ & Practiced \\
\hline Tail cutting & $\begin{array}{l}\text { Allowed, removal of part of the tail, but only until seven days } \\
\text { of age; avoided whenever possible }\end{array}$ & Practiced \\
\hline Marking & $\begin{array}{l}\text { Allowed, with restrictions: identification using tattoos, } \\
\text { eartags, aerosols or paint (provided these are non-toxic) only } \\
\text { prior to transportation to the slaughterhouse }\end{array}$ & Practiced \\
\hline $\begin{array}{l}\text { Feeding during } \\
\text { pregnancy }\end{array}$ & Guaranteed access for all animals; avoidance of hunger & $\begin{array}{l}\text { Minimum for body } \\
\text { condition }\end{array}$ \\
\hline
\end{tabular}

\section{Slaughter}

All abattoirs must have suitable equipment and facilities for unloading animals from the means of transport and protection against adverse weather conditions. Animals in distress or suffering should be slaughtered immediately (MAPA 2000; MADRP 2009).

The Decree-Law No. 30.691/52 which regulates the Industrial and Sanitary Inspection of Products of Animal Origin in Brazil (Presidência da República 1952) was amended by Decrees No. 1.255/62, 2.244/97 and by Decree No. 8.444/2015 (MAPA 2015). Some changes were made due to Brazil's accession to the Treaty of Asuncion, originating from the Southern Common Market (Mercosul). Thus, Brazilian municipalities must adopt modern methods of supplying food of animal origin to the population, requiring the slaughter of animals by butchers to be carried out using humane methods, involving use of instantaneous and effective stunning prior to slaughter (Dias 2000).

In 2008, the Ministry of Agriculture, Livestock and Food Supply (MAPA) and the World Society for the Protection of Animals (WSPA) signed the National Humanitarian Slaughter Program (STEPS). This seeks to improve animal welfare throughout Brazil, through training of federal and professional inspectors working in slaughterhouses, aimed at improving the handling of animals pre-slaughter and at slaughter. The Term of Cooperation had the support of the Brazilian Association of the Producing and Exporting Industry of Swine (Abipecs) (WSPA 2009). Humane slaughtering involves a set of procedures that guarantee the welfare of the animals from embarkation at the production farm until the moment of the desensitization. The animal should have good standards of welfare in all times prior to slaughter, avoiding unnecessary suffering (Bertoloni and Silveira 2003).

The Brazilian Ministry of Agriculture and Livestock (MAPA) established a Permanent Technical Animal Welfare Committee (CTBEA) through Administrative Rule $N^{\circ}$. 524/2011, with the purpose of planning, coordinating, supervising, encouraging and evaluating activities, programs and actions on animal welfare, and also aimed at the economic interests of the various links in the livestock chain (MAPA 2011). In recent years, the MAPA has fostered the adoption of animal welfare practices through partnerships with other public and private institutions, and terms of cooperation, such as those signed by Embrapa Swine and Aves and WSPA (Rosa et al 2013).

According to Rosa et al (2013), several researches have been developed relating the level of animal welfare to various aspects of animal production and science, such as physiology, nutrition, environment, lighting programs, transportation, handling, air quality, noise, among others. Despite this, there are still many challenges to be faced in practice, such as the fact that European legislation has a character of economic and 
consequently implication in raising production costs (Silva 2012).

\section{Final considerations}

The countries of the European Union already have advanced animal welfare legislation. Brazilian pig farms, like all other animal husbandry activities, are still lacking specific legislation that addresses the Brazilian reality, which ends up delaying the effective practice of welfare in productions, abstaining from the population of information about the activity.

Considering the dissemination of knowledge and the growing concern for animal welfare in the European consumer market, every day it is noted that the need for application to livestock production, possibly becoming a basic requirement in the coming years.

New studies are needed to evaluate the legislation, which take into consideration the circumstances of each country. These studies could establish whether the legislation is effective in improving animal welfare, or whether it serves only to increase bureaucracy around the licensing of holdings and safeguard the interests of certain lobbies.

\section{Acknowledgement}

To the Coordination for the Improvement of Higher Education Personnel (CAPES), for granting the scholarship of the Doctoral Sandwich Program Abroad to the corresponding author.

\section{References}

Barbut S, Sosnicki AA, Lonergan SM, Knapp T, Ciobanu DC, Gatcliffe LJ, Huff-Lonergan E, Wilson EW (2008) Progress in reducing the pale, soft and exudative (PSE) problem in pork and poultry meat. Meat Science, 79:46-63.

Bertoloni W, Silveira ETF (2003) Bem-Estar de suínos durante o abate e suas interações na qualidade da carne. Boletim SBCTA, $37: 119-126$.

Broom DM (1991) Animal welfare: concepts and measurement. Journal Animal Science, 69:4167-4175.

CAP - Confederação dos Agricultores de Portugal (2006) Recomendações de Bem-Estar Animal. Lisboa: Confederação dos Agricultores de Portugal, Departamento Técnico. Disponível em: <http://www.cap.pt/0_users/file/Agricultura\%20Portuguesa/Pecuari a/BemEstar\%20Animal/Manual/codigo\%20recomendacoes\%20cro p.pdf $>$ Acesso em abril de 2015.

Conselho Europeu (2004) Regulamento n. ${ }^{0} 1 / 2005$ de 22 de Dezembro de 2004 relativo à protecção dos animais durante o transporte e operações afins e que altera as Directivas 64/432/CEE e 93/119/CE e o Regulamento (CE) n. ${ }^{\circ}$ 1255/97.

Cruz VF, Pereira A, Silva FC (2004) Monitorização de Instalações tendo em vista o bem-estar animal. Actas do Congresso LusoBrasileiro de Tecnologias de Informação e Comunicação na AgroPecuária. Santarém, CD-Rom: 12.
Cruz VF, Grácio, J (2005) Algumas notas sobre a importância das instalações e equipamentos no bem estar anima, em suinocultura. Suinicultura, 66: 32-34.

Dias, EC (2000) A tutela jurídica dos animais. Belo Horizonte: Mandamentos. p. 155.

FAWC - Farm Animal Welfare Council (2009) Five Freedoms. Disponível em: <http://www.fawc.org.uk/freedoms.htm> Acesso em 30 de abril de 2015.

Franchi GA, Nunes MLA, Garcia PR, Silva IJ.O (2012a) Percepção do mercado consumidor de Piracicaba em relação ao bem-estar dos animais de produção. PUBVET, Londrina, V. 6, N. 11, Ed. 198, Art. 1325 ,

Franchi GA, Silva IJO, Vieira FVR, Garcia PR, Pinto ALM (2012b) $\mathrm{O}$ bem-estar animal e a legislação. Disponível em: <https://www.milkpoint.com.br/radar-tecnico/bemestar-ecomportamento-animal/o-bemestar-animal-e-a-legislacao79930n.aspx > Acesso em jan de 2018.

Foppa L, Caldara FR, Machado SP, Moura R, Santos RKS, Nääs IA, Garcia RG (2014) Enriquecimento Ambiental e Comportamento de Suínos: Revisão. Brazilian Journal of Biosystems Engineering. 8:0107 .

Galina AL, Pfüller EE (2015) Análise do bem estar animal e os fatores que influenciam na qualidade da carne suína da Cooperativa Regional Sananduva de Carnes e Derivados Ltda-rs RAMVI, 02:121.

Guy JH, Meads ZA, Schiel RS, Edwards SA (2013) The effect of combining different environmental enrichment materials on enrichment use by growing pigs. Applied Animal Behaviour Science, 144:102-107.

Ludtke CB, Ciocca, JRO, Dandin, T; Barbalho, PC; Vilela, JÁ (2010) Abate Humanitário de Aves. WSPA. Rio de Janeiro, p.120.

Ludtke CB, Dalla Costa OA, Roça RO, Silveira ETF, Athayde NB, Araújo AP, Mello JR A, Azambuja NC (2012) Bem-estar animal no manejo pré-abate e a influência na qualidade da carne suína e nos parâmetros fisiológicos do estresse. Ciência Rural. 42: 532-537

Machado Filho LCP, Hötzel MJ (2000) Bem estar em suínos. In: Seminário Internacional De Suinocultura, São Paulo: Gessuli, p.88105.

MADRP - Ministério da Agricultura, do Desenvolvimento Rural e das Pescas (Portugal) (1998) Decreto-Lei n. ${ }^{\circ}$ 294/98. Estabelece as normas relativas à protecção dos animais durante o transporte $\mathrm{e}$ revoga o Decreto-Lei n. ${ }^{\circ}$ 153/94, de 28 de Maio, e a Portaria n. ${ }^{\circ}$ 160/95, de 27 de Fevereiro. Diário da Republica - 1. ${ }^{a}$ SERIE A, N 216, Pág. 4838.

MADRP - Ministério da Agricultura, do Desenvolvimento Rural e das Pescas (Portugal) (2000) Decreto-Lei n. ${ }^{\circ}$ 64/2000. Transpõe para a ordem jurídica nacional a Directiva $n .{ }^{\circ}$ 98/58/CE, do Conselho, de 20 de Julho, estabelecendo as normas mínimas de protecção dos animais nas explorações pecuárias. Diário da República - I Série-A $\mathrm{N}^{\circ} 95$.

MADRP - Ministério da Agricultura, do Desenvolvimento Rural e das Pescas (Portugal) (2003) Decreto-Lei 135/2003, transpondo para a ordem jurídica nacional a Directiva $n .^{\circ}$ 91/630/CEE, do Conselho, de 19 de Novembro, relativa às normas mínimas de proteç̧ão de suínos, com as alterações que lhe foram introduzidas pelas Directivas n. 2001/88/CE, do Conselho, de 23 de Outubro, e 2001/93/CE, da Comissão, de 9 de Novembro. Diário Da República - I Série-A. N. ${ }^{\circ}$ 147. 
MADRP - Ministério da Agricultura, do Desenvolvimento Rural e das Pescas (Portugal) (1996) Decreto-Lei n. ${ }^{\circ}$ 28/96. O presente diploma transpõe para a ordem jurídica nacional a Directiva $n .{ }^{\circ}$ 93/119/CE, do Conselho, de 22 de Dezembro, relativa à protecção dos animais no abate e ou occisão. Diário da República - I SÉRIEA, N. ${ }^{\circ} 79$.

MADRP - Ministério da Agricultura, do Desenvolvimento Rural e das Pescas (Portugal) (2009) Regulamento (CE) n. ${ }^{\circ}$ 1099/2009 do Conselho de 24 de Setembro de 2009 relativo à protecção dos animais no momento da occisão. Jornal Oficial da União Europeia.

Maia APA, Sarubbi J, Medeiros BBL, Moura DJ (2013) Enriquecimento ambiental como medida para o bem-estar positivo de suínos (Revisão). Revista Eletronica em Gestão, Educação e Tecnologia Ambiental - REGET. 14:2862-2877.

MAPA - Ministério da Agricultura, Pecuária e Abastecimento (Brasil) (2011) Portaria ${ }^{\circ} 524$, de 21 de jun. de 2011. Diário Oficial da União, Brasília, DF, Seção1, p 5.

MAPA - Ministério da Agricultura, Pecuária e Abastecimento (Brasil) (2008) Instrução Normativa $n^{\circ} 56$ de 06 de nov.2008. Diário Oficial da União, Brasília, DF, Seção 1.

MAPA - Ministério da Agricultura, Pecuária e Abastecimento (Brasil) (2013) Boas práticas de manejo, embarque. Secretaria de Desenvolvimento Agropecuário e Cooperativismo - Brasília : MAPA/ACS, $38 \mathrm{p}$.

MAPA - Ministério da Agricultura, Pecuária e Abastecimento (Brasil) (2010) Aves E Suínos - Padronização Das Frequências E Planilhas Para A Verificação Oficial Dos Elementos De Inspeção. Secretaria de Defesa Agropecuária. OFÍCIO CIRCULAR N ${ }^{\circ} 12$ /2010/GAB/DIPOA. Brasília, 31 de março de 2010. Disponível em: < www.consultaesic.cgu.gov.br/.../resposta_pedido_circular\%20122010.doc>

MAPA - Ministério da Agricultura, Pecuária e Abastecimento (Brasil) (2000) Instrução Normativa $n^{\circ} 3$, de 17 de janeiro de 2000. Regulamento técnico de métodos de insensibilização para abate humanitário de animais de açougue. Diário Oficial da União, Brasília. Disponível em: <http://extranet.agricultura.gov.br/sislegisconsulta/consultarLegislacao.do?operacao=visualizar\&id=1793>

Acessado em 04 de maio de 2015.

Ministério da Agricultura (Portugal) (1994) Ministério da Agricultura. Portaria ${ }^{\circ}$. 274/94 - Estabelece as normas mínimas de protecção dos suínos para efeitos de criação e de engorda. Diário da República $-1^{\circ}$ série B. n. ${ }^{\circ} 106$.

Ministério da Agricultura e do Abastecimento Secretaria De Defesa Agropecuária. (Brasil) (2000). Instrução Normativa N 3 de Janeiro de 2000. Diário Oficial da União, seção 1, página 1.

Ordóñez JÁ (2005) Tecnologia de Alimentos: Componentes dos Alimentos e Processos. Porto Alegre: Artmed.

Pandorfi H (2005) Comportamento bioclimático de matrizes suínas em gestação e o uso de sistemas inteligentes na caracterização do ambiente produtivo: suinocultura de precisão. Tese de Doutorado. Escola Superior de Agricultura Luiz de Queiroz, Universidade de São Paulo.

Presidência da República - Brasil (1952) Presidência da República. Decreto $\mathrm{n}^{\circ}$ 30.691/52. Aprova o novo Regulamento da Inspeção Industrial e Sanitária de Produtos de Origem Animal. Diário Oficial da União, Brasília, DF.

Presidência da República - Brasil. (1952) Presidência da República. Decreto $\mathrm{n}^{\circ} 8.444 / 2015$. Altera o Regulamento da Inspeção Industrial e Sanitária de Produtos de Origem Animal, aprovado pelo Decreto ${ }^{\circ}$
30.691, de 29 de março de 1952. Diário Oficial da União, Brasília, DF.

Rosa CO, Civardi JFD, Schlindwein MM, Garcia RG (2013) Bemestar animal na produção de aves e suínos: uma análise teórica. Enciclopédia Biosfera. Centro Científico Conhecer - Goiânia, 9, p.451.

Silva RBTR (2012) Itens normativos de bem-estar animal e a produção brasileira de frangos de corte. Tese de Doutoramento. Campinas, Universidade de Campinas - Unicamp, 97p.

Veloni ML, Prado PL, Arssuffi BM, Ballestero MCM, Oliveira MG, Abreu PB, Oliveira LG (2013) Bem-Estar Animal Aplicado nas Criações de Suínos e suas Implicações na Saúde dos Rebanhos. Revista científica Eletrônica de Medicina Veterinária. Ano XI , n.21.

Warriss PD, Brown SN, Paściak P (2006) The color of the adductor muscle as a predictor of pork quality in the loin. Meat Science, 73:565-569.

WPSA Brasil (2009) Programa nacional de abate humanitário. Disponível em: <http://www.worldanimalprotection.org.br/noticias/2009/Lancamen to-do-Programa-Nacional-de-Abate-Humanitario-STEPS.aspx > Acessado em 28 de abril de 2015. 